\title{
P̈̈̈̈KIRJOITUS
}
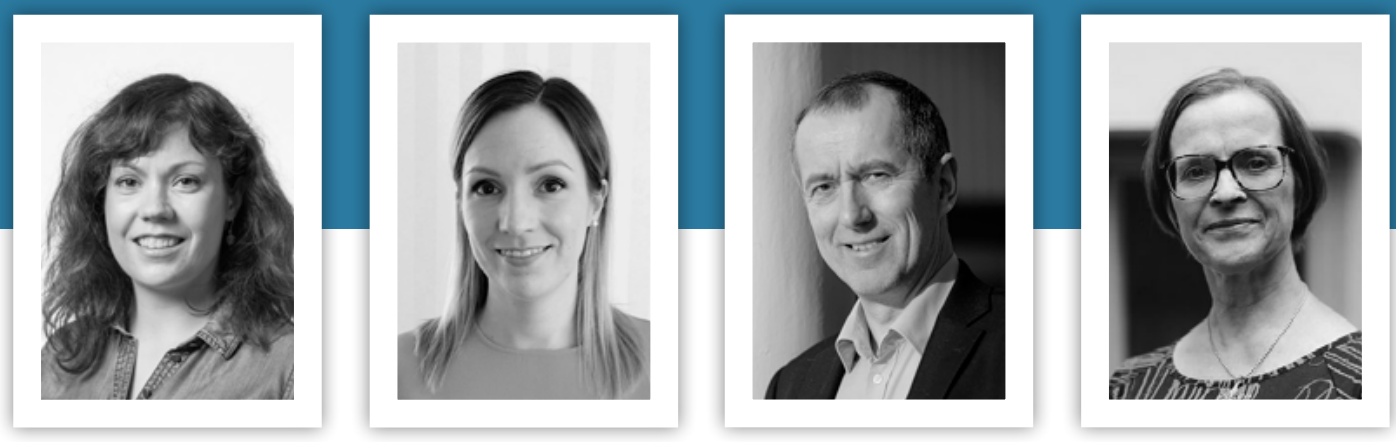

\section{EKOSOSIAALINEN SIVISTYS ON YHTEISÖLLISTÄ SIVISTYMISTÄ}

$\mathrm{T}$

ässä teemanumerossa sivistys liitetään ekososiaalisiin kysymyksiin ja planetaarisiin haasteisiin. Onko näihin suuriin, viheliäisiin kysymyksiin (wicked problems, vrt. Rittel \& Webber, 1973) mahdollista tarttua arjen pienin kestävin teoin, kehittämällä ja opettelemalla uusia toisin toimimisen taitoja? Aikuisten oppiminen ja sivistystyöhön osallistuminen voivat liittää pienet teot isoihin ratkaisupyrkimyksiin, avata näkökulmia elonyhteisöjen välisten suhteiden pohdintaan ja tarjota vaikuttamismahdollisuuksia.

AIKUISKASVATUKSEN TUTKIMUKSESSA JA TYÖSSÄ on herätty pohtimaan ekologisen ja sosiaalisen keskinäisriippuvuutta sekä käsitteellisen ymmärryksen että oppimiskäytäntöjen tasolla. Niin sanottu ekososiaalinen hyve-etiikka haastaa meitä luopumaan ihmiskeskeisyydestä ja kohdistamaan katseen ”enemmän-kuin-ihmisen maailmaan" kuten Jani Pulkki toteaa tiedeartikkelissaan.

Keskinäisriippuvuuden oppiminen voi käynnistyä monilajisen yhteiselon tunnusteluna ihmisen ja muiden lajien, esimerkiksi "kiusalliseksi koettujen" ampiaisten, suhteissa. Valepesiä virkkaamalla ihminen - ainakin omasta perspektiivistään - neuvottelee ampiaisten kanssa yhteisestä elintilasta ja etäisyydestä, Minna Santaoja osoittaa omassa tiedeartikkelissaan.

Aikuiskasvatuksessa odotukset kohdistuvat kansalaisliikkeisiin ekososiaalisena sivistäjänä. Miten esimerkiksi Erja Laakkosen tarkastelema pohjoiskarjalainen Kohtuus vaarassa -ryhmä kiinnittää huomiomme kohtuullisiin elämäntapoihin ja kulutuskeskeisyyden ongelmallisuuteen?

Teemanumeron tekstit kuvastavat ekososiaaliseen sivistykseen sisältyviä jännitteitä. Kriittisyys arjen valinnoissa ja yksilön valintojen suhde rakenteelliseen muutokseen on haastava yhtälö: uutta tietoa saatetaan kyseenalaistaa, ja sitä voi olla vaikeaa omaksua tai muuntaa teoiksi. Globaalit kriisit pakottavat meidät valmistautumaan epävarmaan tulevaisuuteen radikaalein tai hienovaraisemmin toimin - esimerkistä käyvät omavaraistalous tai vastuullisuusasiantuntijat. Ekososiaalisen sivistyksen edistämispyrkimykset voivat paitsi ratkaista tulevaisuuden planetaarisia kriisejä myös synnyttää uusia, jos ne yhdistämisen sijaan erottavat ihmisiä. Jotkut tutkijat näkevät ai- 


\section{YKSILÖN VALINTOJEN SUHDE RAKENTEELLISEEN}

\section{MUUTOKSEEN ON HAASTEELLINEN YHTÄLÖ.}

noana vaihtoehtona systeemitason toimet, joissa yksilöllinen kytketään yhteisölliseen muutokseen (Rockström 2020).

Teemanumero juhlistaa Sivistystyön Vapaus ja Vastuu (SVV) -yhteistyöohjelman kymmenvuotisuutta. Se on tuotettu SVV-ohjelman ja Aikuiskasvatuksen toimituskunnan yhteistyönä. Ohjelma on pyrkinyt vahvistamaan vapaaseen sivistystyöhön kohdistuvaa tutkimusta tukemalla tutkijoiden, käytännön toimijoiden ja politiikantekijöiden vuoropuhelua (ks. Pätäri ym., 2019).

Teemanumero virittää tutkimuksellista keskustelua ajankohtaisista ja kiperistä sosiaalisista, taloudellisista ja ekologisista kysymyksistä. Vastaukset ovat kaikkea muuta kuin yksinkertaisia. Siksi vuoropuhelua eri sivistystyötahojen välillä tarvitaan tulevaisuudessakin.

Satu Heimo, Annika Pastuhov, Björn Wallén ja Hanna Toiviainen

teemanumeron päätoimittajat

\section{LÄHTEET}

Pätäri, J., Teräsahde, S., Harju, A., Manninen, J. \& Heikkinen, A. (toim.) 2019. Vapaa sivistystyö eilen, tänään ja huomenna. Vapaan sivistystyön rooli, asema ja merkitys suomalaisessa yhteiskunnassa ja koulutusjärjestelmässä. Helsinki: Sivistystyön vapaus ja vastuu \& Vapaa sivistystyö ry.

Rittel, H., \& Webber, M. (1973). Dilemmas in a General Theory of Planning. Policy Sciences, 4(2), 155-169.

Rockström, J. (2020): Social tipping mechanism could spark societal change. Stockholm Resilience Centre / Stockholm University. Blogikirjoitus 22.1.2020. 